\title{
Direct iminization of PEEK
}

\author{
Article
}

Accepted Version

Manolakis, I., Cross, P. and Colquhoun, H. (2011) Direct iminization of PEEK. Macromolecules, 44 (19). pp. 7864-7867. ISSN 0024-9297 doi: https://doi.org/10.1021/ma201606q Available at https://centaur.reading.ac.uk/24209/

It is advisable to refer to the publisher's version if you intend to cite from the work. See Guidance on citing.

Published version at: http://pubs.acs.org/doi/full/10.1021/ma201606q

To link to this article DOI: http://dx.doi.org/10.1021/ma201606q

Publisher: American Chemical Society

All outputs in CentAUR are protected by Intellectual Property Rights law, including copyright law. Copyright and IPR is retained by the creators or other copyright holders. Terms and conditions for use of this material are defined in the End User Agreement.

\section{www.reading.ac.uk/centaur}

\section{CentAUR}

Central Archive at the University of Reading

Reading's research outputs online 


\title{
Direct Iminization of PEEK
}

\author{
Ioannis Manolakis, ${ }^{\dagger}$ Paul Cross $^{\S}$ and Howard M. Colquhoun $*^{\dagger}$ \\ Department of Chemistry, University of Reading, Whiteknights, Reading, RG6 6AD, UK; \\ Cytec Engineered Materials Ltd, Wilton Centre, Redcar, Teesside, TS10 4RF, UK
}

EMAIL: h.m.colquhoun@rdg.ac.uk

${ }^{\dagger}$ University of Reading

${ }^{\S}$ Cytec Engineered Materials

\section{RECEIVED DATE}

TITLE RUNNING HEAD: Iminization of PEEK

\begin{abstract}
Semi-crystalline poly(ether ketone)s are important high-temperature engineering thermoplastics, but are difficult to characterize at the molecular level because of their insolubility in conventional organic solvents. Here we report that polymers of this type, including PEEK, react cleanly at high temperatures with low-volatility aralkyl amines to afford stable, noncrystalline poly(ether-imine)s, which are readily soluble in solvents such as chloroform, THF and DMF and so characterizable by conventional size-exclusion chromatography.
\end{abstract}

KEYWORDS: PEEK, iminization, poly(ether imine)s, GPC, NMR. 


\section{Introduction}

Semicrystalline aromatic poly(ether ketone)s are an industrially-important class of high-performance thermoplastics with outstanding physico-chemical properties. ${ }^{1,2}$ For example, PEEK (Chart 1) is widely used in situations that require thermo-oxidative and mechanical stability at high temperatures, or in contact with organic solvents, and it finds increasing application as a matrix polymer in carbon-fibre composites for aerospace applications. ${ }^{3}$ However, the very resistance to dissolution of such materials is a major obstacle to their detailed characterization, so that a full understanding of the relationship between properties and structure at the molecular level is often difficult to achieve. Gel-permeation chromatographic analysis of PEEK and some related semi-crystalline poly(ether ketone)s may be carried out in a mixture of phenol and 1,2,4-trichlorobenzene, ${ }^{4,5,6,7}$ but this technique requires a combination of high column temperatures (typically $>115{ }^{\circ} \mathrm{C}$ ) and corrosive/hazardous solvents, so that relatively specialized GPC systems are required. An alternative approach to the characterization of poly(ether ketone)s, for example by GPC or light scattering, would be to convert the polymer, without degrading its molecular weight or changing its polydispersity, to an amorphous and therefore more soluble chemical derivative.

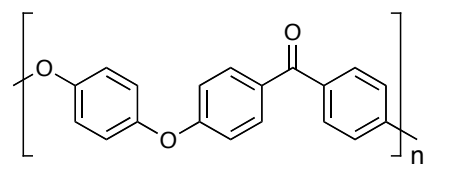

PEEK

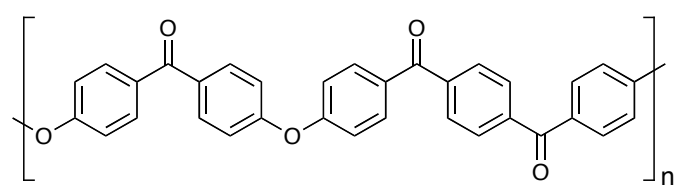

PEKEKK

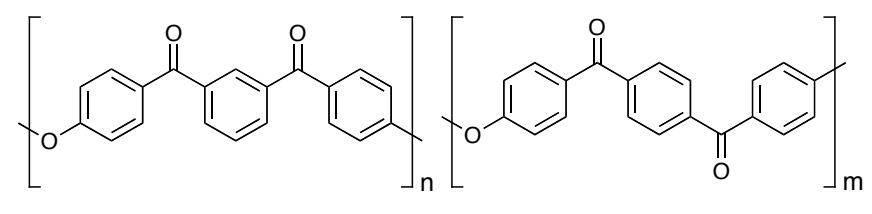

PEKK (family of 1,3/1,4-copolyketones)

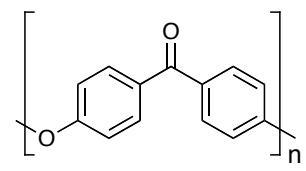

PEK

Chart 1. Some industrially-important poly(ether ketone)s 
For example, PEEK may be sulfonated at the hydroquinone residue simply by dissolving it at ambient temperature in concentrated (96-98\%) sulfuric acid, and the resulting, amorphous, polysulfonate ionomer is soluble in dipolar aprotic solvents. ${ }^{8,9}$ Lithium salts of sulfonated PEEK can then be analyzed by room-

temperature GPC in $N$-methylpyrrolidone. ${ }^{10}$ However this approach is limited, in that many potentially important poly(ether ketone)s such as PEK, PEKEKK and PEKK (Chart 1) are not sulfonated under such conditions (since every ring carries at least one deactivating carbonyl group), and so cannot be characterized by this method. We have recently reported a more general methodology which depends on derivatization of the carbonyl groups by converting these to cyclic dithioketal units in the presence of an alkanedithiol and boron trifluoride, using strong-acid solvents such as chloroform/trifluoroacetic acid mixtures to dissolve the starting polymer. ${ }^{11,12}$ Here we report a different but related approach to the problem, in which we show that semicrystalline aromatic poly(ether ketone)s, including PEEK, can be converted cleanly to amorphous, soluble poly(ether imine)s by reaction with low-volatility aralkyl amines at high temperatures.

\section{Experimental}

Instrumentation, methods and materials: Details of instrumentation and analytical methods (IR, NMR, DSC, GPC, TGA, solution viscometry) have been described in a recent publication. ${ }^{12}$ Commercialgrade samples of PEEK $\left(\eta_{\text {inh }}=0.82 \mathrm{dL} \mathrm{g}^{-1}\right.$ in $\left.96 \% \mathrm{H}_{2} \mathrm{SO}_{4}\right)$ were donated by Cytec Engineered Materials Ltd, and research samples of PEK $\left(\eta_{\mathrm{inh}}=0.98 \mathrm{dL} \mathrm{g}^{-1}\right.$ in $\left.96 \% \mathrm{H}_{2} \mathrm{SO}_{4}\right)$ were kindly provided by ICI plc. Diphenyl sulfone, 2,2-diphenylethylamine and 3,3-diphenylpropylamine were purchased from Acros and were used without further purification.

Iminization of poly(ether ketone)s: A sample of PEEK powder $(0.577 \mathrm{~g}, 2.00 \mathrm{mmol})$ was placed in a reaction tube equipped with a nitrogen inlet and mechanical stirrer, together with diphenyl sulfone (9.0 g, $41 \mathrm{mmol})$ and 2,2-diphenylethylamine (1.972 $\mathrm{g}, 10 \mathrm{mmol})$ The system was stirred under a gentle, continuous purge of dry nitrogen and heated slowly $\left(90^{\circ} \mathrm{C} \mathrm{h}^{-1}\right)$ to $315^{\circ} \mathrm{C}$ to dissolve the polymer. The temperature was then lowered to $270{ }^{\circ} \mathrm{C}$ and the solution was stirred at this temperature for $3 \mathrm{~h}$, giving a clear, viscous, bright yellow solution. The reaction mixture was then poured onto an aluminium tray to cool. The resulting beige solid was dissolved in dichloromethane $(100 \mathrm{~mL})$ and the polymer recovered as a pale 
yellow powder by precipitation in methanol $(300 \mathrm{~mL})$. Traces of diphenyl sulfone were removed by extracting the polymer in refluxing methanol for $1 \mathrm{~h}$, and the product poly(ether imine), $\mathbf{1}$, was then filtered off and dried at $80{ }^{\circ} \mathrm{C}(0.83 \mathrm{~g}, 89 \%$ yield $)$. Analogous poly(ether imine)s $\mathbf{2}, \mathbf{3}$ and $\mathbf{4}$ were obtained under the same conditions by reactions, respectively, of PEEK with 3,3-diphenylpropylamine, PEK with 2,2diphenylethylamine, and PEK with 3,3-diphenylpropylamine.

Characterization of poly(ether imine)s: Polymer 1. IR (film from chloroform) $v_{\max } / \mathrm{cm}^{-1}: 3026$ (C$\left.\mathrm{H}_{\mathrm{Ar}}\right), 2914(\mathrm{C}-\mathrm{H}), 1615(\mathrm{C}=\mathrm{N}), 1599\left(\mathrm{C}=\mathrm{C}_{\mathrm{Ar}}\right), 1491$ (C-C), 1223 (C-O-C), 1164 (C-O-C); ${ }^{1} \mathrm{H}$ NMR (250 $\left.\mathrm{MHz}, \mathrm{CDCl}_{3}\right): \delta_{\mathrm{H}}(\mathrm{ppm}) 7.40\left(2 \mathrm{H}, \mathrm{m}, \mathrm{H}_{\mathrm{o}}\right), 7.25-6.84\left(20 \mathrm{H}, \mathrm{m}, \mathrm{H}_{\mathrm{b}}, \mathrm{H}_{\mathrm{d}}, \mathrm{H}_{\mathrm{p}}, \mathrm{H}_{\mathrm{e}}, \mathrm{H}_{\mathrm{k}}, \mathrm{H}_{\mathrm{l}}, \mathrm{H}_{\mathrm{m}}\right), 4.55\left(1 \mathrm{H}, \mathrm{H}_{\mathrm{i},}\right.$ tr, J $=5 \mathrm{~Hz}), 4.06\left(2 \mathrm{H}, \mathrm{H}_{\mathrm{h}} \mathrm{d}, \mathrm{J}=7.5 \mathrm{~Hz}\right) ;{ }^{13} \mathrm{C} \mathrm{NMR}\left(100 \mathrm{MHz}, \mathrm{CDCl}_{3}\right): \delta_{\mathrm{C}}(\mathrm{ppm}) 167.2\left(\mathrm{C}_{\mathrm{g}}\right), 159.3\left(\mathrm{C}_{\mathrm{q}}\right)$, $157.9\left(\mathrm{C}_{\mathrm{c}}\right), 152.3\left(\mathrm{C}_{\mathrm{a}}\right), 143.4\left(\mathrm{C}_{\mathrm{j}}\right), 135.2\left(\mathrm{C}_{\mathrm{f}}\right), 130.9\left(\mathrm{C}_{\mathrm{n}}\right), 130.1\left(\mathrm{C}_{\mathrm{o}}\right), 129.7\left(\mathrm{C}_{\mathrm{e}}\right), 128.5\left(\mathrm{C}_{\mathrm{k}}\right), 128.3\left(\mathrm{C}_{\mathrm{l}}\right)$, 126.2 $\left(\mathrm{C}_{\mathrm{m}}\right), 121.1\left(\mathrm{C}_{\mathrm{b}}\right), 117.5\left(\mathrm{C}_{\mathrm{d}}, \mathrm{C}_{\mathrm{p}}\right), 58.8\left(\mathrm{C}_{\mathrm{h}}\right), 52.6\left(\mathrm{C}_{\mathrm{i}}\right) ; \eta_{\text {inh }}\left(\mathrm{CHCl}_{3}\right) 0.25 \mathrm{dL} \mathrm{g}^{-1} ; T_{\mathrm{g}}$ (onset) = $128{ }^{\circ} \mathrm{C}$; GPC (RI, THF, $\left.25^{\circ} \mathrm{C}\right): M_{\mathrm{n}}=28 \mathrm{kD}, M_{\mathrm{w}}=49 \mathrm{kD}$; Calcd. for $\mathrm{C}_{33} \mathrm{H}_{25} \mathrm{O}_{2} \mathrm{~N}: \mathrm{C} 84.77, \mathrm{H} 5.39, \mathrm{~N} 2.99$; Found: C 84.27, H 5.37, N 3.01\%. Poly(ether imine)s $\mathbf{2}, 3$ and $\mathbf{4}$ were characterised by analogous methods, with details given in Table 1 and in the Supporting Information.

\section{Results and Discussion}

Semi-crystalline aromatic poly(ether ketone)s, specifically PEEK and PEK (Chart 1) were found to react cleanly with the high-boiling aralkyl amines 2,2-diphenylethylamine and 3,3-diphenylpropylamine in diphenyl sulfone solution at $270{ }^{\circ} \mathrm{C}$, affording poly(ether imine)s $\mathbf{1 , 2}, \mathbf{3}$ and $\mathbf{4}$ (Chart 2) in high yield. These polyimines are amorphous by GPC, with their glass transition temperatures rather lower than those of their semi-crystalline parent polymers. The more flexible 3,3-diphenylpropyl side-chains lead to lower Tg's than the analogous 2,2-diphenylethyl derivatives. All four poly(ether imine)s are readily soluble in conventional organic solvents such as chloroform and tetrahydrofuran, enabling them to be characterised easily by GPC (Table 1). The values obtained for $M_{\mathrm{w}}$ and $M_{\mathrm{n}}$ also show a pattern, in that the 3,3diphenylpropyl derivatives consistently give lower values than their 2,2-diphenylethyl analogues, relative to polystyrene standards. It seems that the greater flexibility of the former side-chain must allow the polymer molecule to adopt a more compact overall conformation. 
Table 1. Characterisation data for poly(ether imine)s 1 - 4

\begin{tabular}{|l|cccc|}
\hline & $\mathbf{1}$ & $\mathbf{2}$ & $\mathbf{3}$ & $\mathbf{4}$ \\
\hline$\eta_{\text {inh }}\left(\mathrm{dL} \mathrm{g}^{-1}\right)^{\mathrm{a}}$ & 0.25 & 0.32 & 0.24 & 0.25 \\
$M_{\mathrm{w}}(\mathrm{kD})^{\mathrm{b}}$ & 49 & 45 & 42 & 36 \\
$M_{\mathrm{n}}(\mathrm{kD})^{\mathrm{b}}$ & 28 & 21 & 22 & 17 \\
$T_{\mathrm{g}}\left({ }^{\circ} \mathrm{C}\right)^{\mathrm{c}}$ & 128 & 112 & 130 & 109 \\
\hline
\end{tabular}

${ }^{a}$ At $25^{\circ} \mathrm{C}$ in chloroform. ${ }^{\mathrm{b}}$ By GPC at $25^{\circ} \mathrm{C}$ in THF. ${ }^{\mathrm{c}}$ By DSC (onset temperature).

Arylamines such as 4-hexyloxyaniline and 3,5-di-t-butylaniline failed entirely to react with poly(ether ketone)s under these conditions, presumably because of the lower nucleophilicity of aromatic amino groups. It should be noted however that an arylimine derivative of PEEK was previously obtained by polycondensation of a pre-formed imine monomer (the phenylimine derivative of 4,4'difluorobenzophenone) with hydroquinone, ${ }^{13,14}$ to give a poly(ether imine), (5), analogous to $\mathbf{1}$ and 2. 


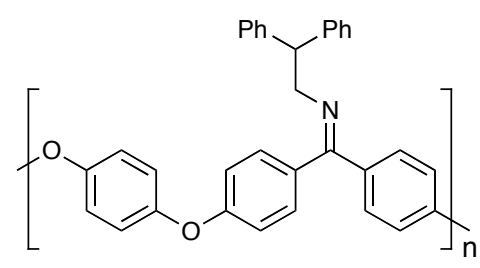

1

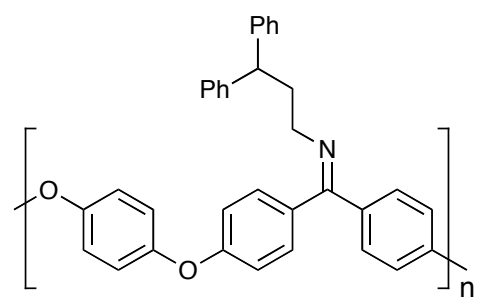

2<smiles>COc1ccc(C(=NCC(c2ccccc2)c2ccccc2)c2ccc(C)cc2)cc1</smiles>

3

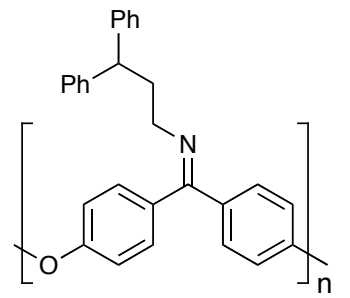

4

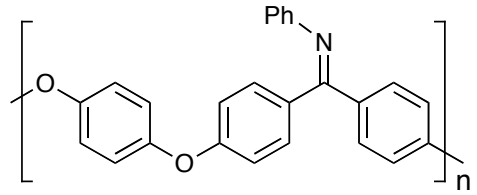

5

Chart 2. Poly(ether imine)s obtained by direct iminization of PEEK (1 and 2) and PEK (3 and 4), and by polycondensation of hydroquinone with the phenylimine of 4,4'-difluorobenzophenone (5).

Analysis of polymers 1-4 by ${ }^{1} \mathrm{H} \mathrm{NMR}$ in $\mathrm{CDCl}_{3}$ showed no residual aromatic resonances associated with ether-ketone sequences, indicating at least $99 \%$ conversion of the starting polymers. Aliphatic resonances arising from the protons of the aralkyl side-chains were generally well resolved, and integration of these against the aromatic signals confirmed essentially quantitative incorporation of the amine. Interestingly, ${ }^{13} \mathrm{C}$ NMR spectra of polymers 1-4 showed sequence-related splitting of several in-chain aromatic resonances, arising from the unsymmetrical geometry of the imine unit. 


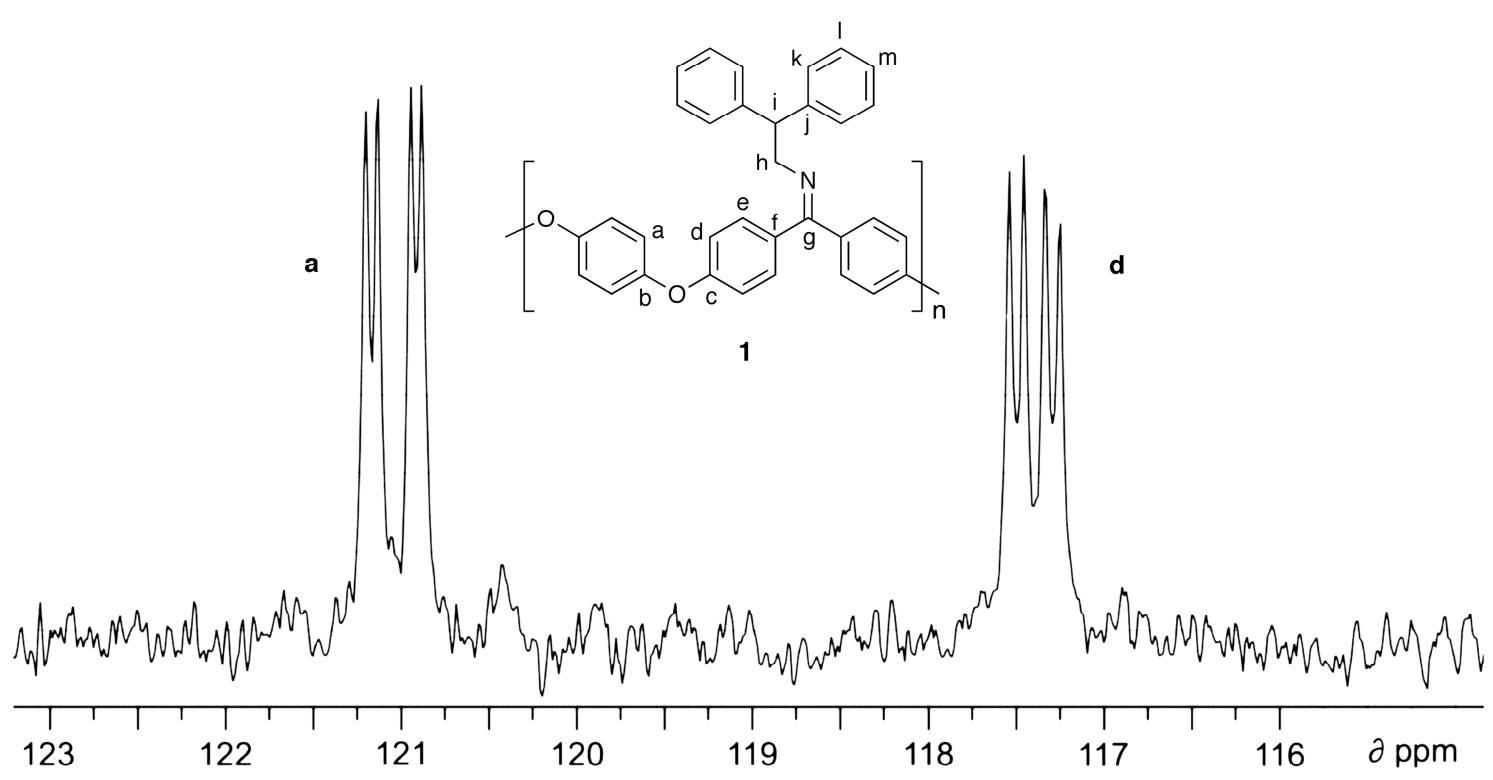

Figure 1. ${ }^{13} \mathrm{C} \mathrm{NMR}$ spectrum $\left(175 \mathrm{MHz}, \mathrm{CDCl}_{3}\right)$ of polymer 1 in the range $115-123$ ppm, showing sequence-related splitting of the resonances associated with carbons $C_{a}$ and $C_{d}$. See also Figure 2 .

This phenomenon was noted previously for polymer $\mathbf{5},{ }^{14}$ but not analysed in any detail. In the present work a fourfold splitting was observed for signals assigned to the carbons ortho to oxygen in both the "hydroquinone" $\left(\mathrm{C}_{\mathrm{a}}\right)$ and "benzophenone" $\left(\mathrm{C}_{\mathrm{d}}\right)$ residues (Figure 2). These carbons are represented by just two single resonances in the ${ }^{13} \mathrm{C}$ NMR spectrum of PEEK itself, ${ }^{15}$ where the three-ring "chemical repeat unit" is symmetrical about the centre of the hydroquinone residue. However, this symmetry is lost on iminization, resulting in three different possible geometrical environments for the repeat unit as shown in Figure 3. In this context, the orientation of each $N$-aralkyl group can be defined as syn or anti with respect to the central hydroquinone residues. Two of the resulting sequences (anti/anti and syn/syn) provide symmetrical environments for the hydroquinone ring and so give rise to just two different "ortho" resonances, representing four carbons each. However, the third possible sequence (anti/syn) - and its directionally-degenerate syn/anti arrangement - result in an unsymmetrical environment for the central aromatic ring and so give rise to two further resonances of this type, each again representing four carbons (Figure 2). As detailed in the Supporting Information, the same reasoning holds for carbon $C_{d}$ in the "benzophenone" residue, providing a parallel explanation for the fourfold splitting of its ${ }^{13} \mathrm{C}$ NMR resonance, as seen in Figure 1. 

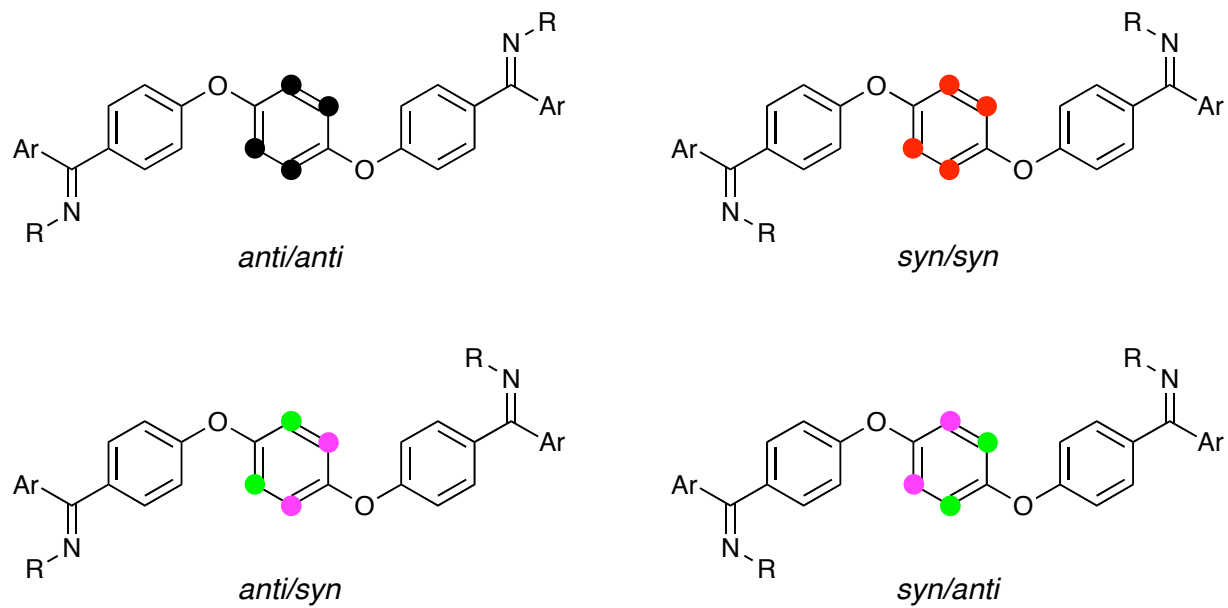

Figure 2. The different types of carbon atom in the monomer sequences found in polymers $\mathbf{1}$ and 2. Colours indicate magnetically equivalent positions, and show why four ${ }^{13} \mathrm{C}$ resonances of equal intensity are observed for the carbon atoms $\left(\mathrm{C}_{\mathrm{a}}\right)$ ortho to oxygen in the central "hydroquinone" residue of polymers $\mathbf{1}$ and $\mathbf{2}$, as shown in the spectrum in Figure 1.

In conclusion, we have developed a clean and convenient iminization process for the derivatization of semicrystalline aromatic poly(ether ketone)s, exemplified for PEEK and PEK. This process yields amorphous, readily-soluble poly(ether imine)s which can be characterised in detail by NMR spectroscopy, GPC, and (potentially) other solution-based techniques such as dynamic light scattering, thereby enabling molecularlevel characteristics of the starting poly(ether ketone)s to be inferred.

\section{Acknowledgement}

We thank Cytec Engineered Materials Ltd., the University of Reading, and EPSRC for support of this work (a PhD studentship to IM).

\section{Supporting Information Available}

Synthesis and characterisation of poly(ether imine)s $\mathbf{1}-\mathbf{4}$ including thermal, spectroscopic, GPC and elemental analyses. Gel permeation chromatograms for poly(ether imine)s 1 - 4. Further analysis of sequence-effects in the ${ }^{13} \mathrm{C}$ NMR spectra of poly(ether imine)s. ${ }^{1} \mathrm{H}$ NMR spectrum of polymer 2. 


\section{References}

$1 \quad$ Staniland, P. A., "Poly(ether ketone)s". In Comprensive Polymer Science; Allen, G.; Bevington, J. C., Eds. Pergamon: Oxford, 1989; Vol. 5, 483-497

2 Attwood, T. E.; Dawson, P. C.; Freeman, J. L.; Hoy, L. R. J.; Rose, J. B.; Staniland, P. A. Polymer 1981, 22, 1096-1103.

3 Hergenrother, P. M. High Perf. Polym., 2003, 15, 3-45

4 Devaux, J.; Delimoy, D.; Daoust, D.; Legras, R.; Mercier, J. P.; Strazielle, C.; Nield, E.Polymer 1985, 26, 1994-2000.

Daoust, D.; Devaux, J.; Godard, P.; Strazielle, C. Macromol. Chem. Phys. 1994, 195, 329-345.

6 Teasley, M. F.; Hsiao, B. S. Macromolecules 1996, 29, 6432-6441.

7 Teasley, M. F.; Wu, D. Q.; Harlow, R. L. Macromolecules 1998, 31, 2064-2074.

8 Bishop, M. T.; Karasz, F. E.; Russo, P. S.; Langley, K. H. Macromolecules 1985, 18, 86-93.

9 Daoust, D.; Godard, P.; Devaux, J.; Legras, R.; Strazielle, C. Polymer 1994, 35, 5491-5497.

10 Daoust, D.; Godard, P.; Devaux, J.; Legras, R.; Strazielle, C. Polymer 1994, 35, 5498-5503.

11 Colquhoun, H. M.; Paoloni, F. P. V.; Drew, M. G. B.; Hodge, P. Chem. Commun. 2007, 33653367.

12 Colquhoun, H. M.; Hodge, P.; Paoloni, F. P. V.; McGrail, P. T.; Cross, P. Macromolecules, 2009, 42, 1955-1963.

13 Mohanty, D. K.; Lowery, R. C.; Lyle, G. D.; McGrath, J. E. Int. SAMPE Symp. Exhib. 1987, 32, 408-419

14 Lindfors, B. E.; Mani, R. S.; McGrath, J. E.; Mohanty, D. K. Makromol. Chem., Rapid Commun. 1991, 12, 337-345.

15 Colquhoun, H. M. Polym. Prepr., Am. Chem. Soc. Div. Polym. Chem. 1984, 25 (2), 17-18. 


\title{
For Table of Contents Use Only
}

\section{Direct Iminization of PEEK}

\author{
Ioannis Manolakis, Paul Cross and Howard M. Colquhoun*
}

Department of Chemistry, University of Reading, Whiteknights, Reading, RG6 6AD, UK; Cytec Engineered Materials Ltd, Wilton Centre, Redcar, Teesside, TS10 4RF, UK

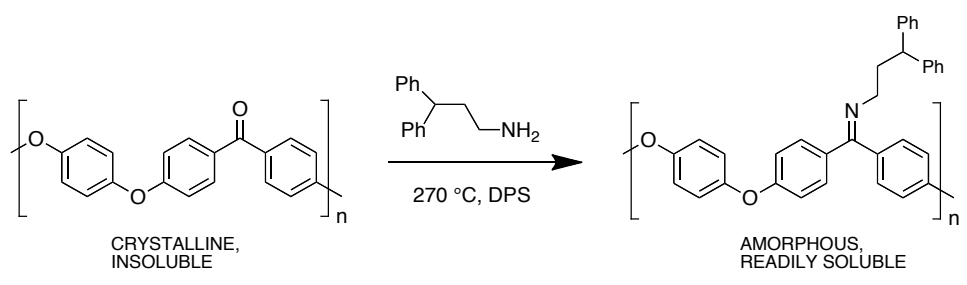

